\title{
Able Bodies
}

W hen I was growing up I used to have these frightening dreams in which I had no use of my arms or legs. I was helpless to do anything for myself and could only watch the world walk by.

Armchair psychoanalysts and dream interpreters would have a field day with those dreams, especially since they occurred during the height of my adolescent/teen years, when simple problems were major catastrophes to the 14-year-old mind. I was a typical kid, growing up in a typical small town, living the typical life that teens in the '80s lived. I never tried to figure out what those dreams meant, nor did I want to.

But they did weigh heavily on my mind, and they got me asking the big "What if?" question. What if I really did lose the use of my arms and legs? How would my life be different? Where would I end up?

Then, early in my career, I was working in public relations for a private university in western New York when I met a professor who had been hit by a bus while riding his bike. His body was mangled in the accident; indeed, his spine had snapped from the force of the crash. The accident left him a quadriplegic with extremely limited use of one hand, which he used to work the joystick steering mechanism of his wheelchair with surprising ease.

Though he had virtually no use of his arms and legs, this man got himself to work each day, taught three classes, conducted research, and had a healthy social life. One might argue he did more than do some people who have full use of their appendages. Thanks to a plethora of software programs and other technologies that allow people with disabilities to perform day-to-day functions, this professor was able to live a productive and somewhat normal life.

For his computing needs he used a voice recognition program, which automatically typed his words and followed simple commands such as "save," "print," and "close"; and a visual mouse, a device that moved the onscreen pointer to wherever his eyeballs commanded. His lectures were decidedly low-tech, relying more on textbooks and handouts than the computer. The professor had a workaround for everything in his professional life, making him just as able as anyone else on the teaching

\section{Alternative $\mathbf{~ H C I}$}

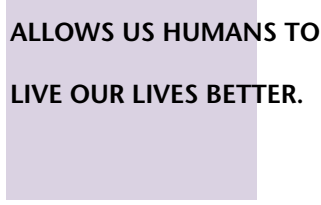

and research staff at the college.

The ADA (Americans with Disabilities Act) of 1990 helped spur a lot of the innovation surrounding perceptual interfaces, and these days more vendors are including ADA requirements in the initial stages of their technology plans, not just regarding them as an afterthought. The result has been software-and hardware-that is more user friendly for people of all abilities.

Perceptual interfaces are just one component of a larger research discipline known as alternative HCI (human-computer interaction), but they are all dedicated to achieving the same basic goal: helping us humans live our lives better. Be it ubiquitous computing (the subject of Gaetano Borriello's article, "The Invisible Assistant"), machine perception (the premise behind James Crowley's article, "Social Perception"), or context-aware computing (the subject of "Too Much Information," a collaborative effort written by members of the Social Computing Group at IBM), more companies are recognizing the need to understand the human element in developing new technology.

Of course, developing for the human element can be tricky, as everyone knows that no two people ever act the same way in any given situation. By understanding some fundamentals of human behavior, however, technology vendors are finding it easier to make technology usage a more personal experience. I don't think my professor friend ever could have accomplished what he did had he not had been able to take advantage of certain technologies, and I shudder to think how his life might have turned out otherwise. It would have been a waste of an incredible mind and a brilliant researcher.

If alternative HCI has been able to help him live a full life, just imagine what it can do for the able-bodied population. Q

CHARLENE O'HANLON, editor of ACM Queue, welcomes your thoughts and opinions. E-mail her at cohanlon@ acmqueue.com. 